\title{
TWO KAKIEMON BIJIN IN THE PRINCESSEHOF MUSEUM: THE EROTIC APPEAL OF ROBES AND HAIRSTYLES
}

In 2015, with the generous support of the Rembrandt Association (Vereniging Rembrandt), the Princessehof National Museum of Ceramics (Keramiekmuseum Princessehof) in Leeuwarden acquired two Kakiemon figures of bijin (beautiful ladies) made in Japan around I680 (fig. I). They are not only a wonderful new addition to the permanent display of the Princessehof's collection, but because of their extraordinary refinement and rarity are also a highlight of the Memory of the Netherlands Collection (Geheugen van Nederland), a most charming 'National Treasure'. These two porcelain figures represent courtesans. They have extravagant coiffures and are clothed with layer upon layer of the finest robes.

My remarks centre on questions probably typical for a Westerner looking at these fine figures more than 300 years after they were made in Japan and exported to Europe: what makes these figures of courtesans, or high

Fig. 1 (left)

Two standing Kakiemon bijin figures, Hizen ware, porcelain with iron-red, blue, green, yellow and black enamels, left: h. ca. $39.3 \mathrm{~cm}$; right: h. $38.4 \mathrm{~cm}$, Japan, Edo period, ca. 1670-1680, Keramiekmuseum Princessehof, inv.nos. MPH 2016-001 and MPH 2016-002. Photo: Johan van der Veer

Fig. 2 (right)

The eyes, detail of the face. Photo: Johan van der Veer class prostitutes, sexually appealing? The Kakiemon bijin are fine examples to use to present a few reflections on the culturally defined concepts of idealised feminine beauty and eroticism in the East and West. It seems that in most cultures opinions of feminine beauty draw heavily on the face. Looking at the faces of the two Kakiemon bijin it is difficult - at least for us Westerners today - to guess their age, and their features do not seem to represent individual personalities (fig. 2). But these are well-known Western clichés. For contemporary Japanese these ladies certainly looked young, and representations of high-ranking courtesans were expected to portray an idealised, not realistic, beauty that was comparable to depictions in traditional Japanese portraits. However, their expressions are far from stereotypical, but are gentle and sensitive. At the same time, they look at us self-confidently, as if they are welcoming us.

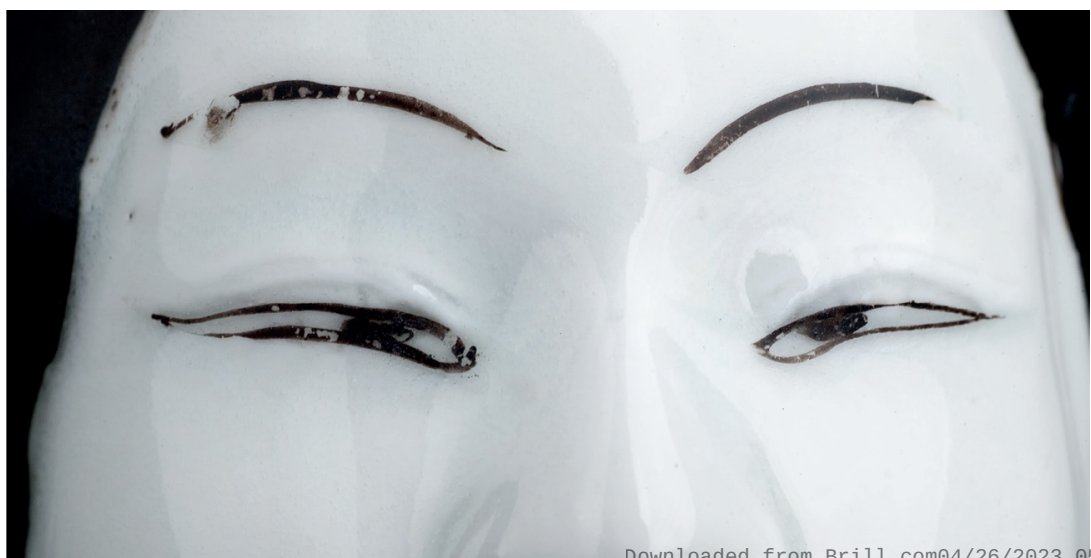



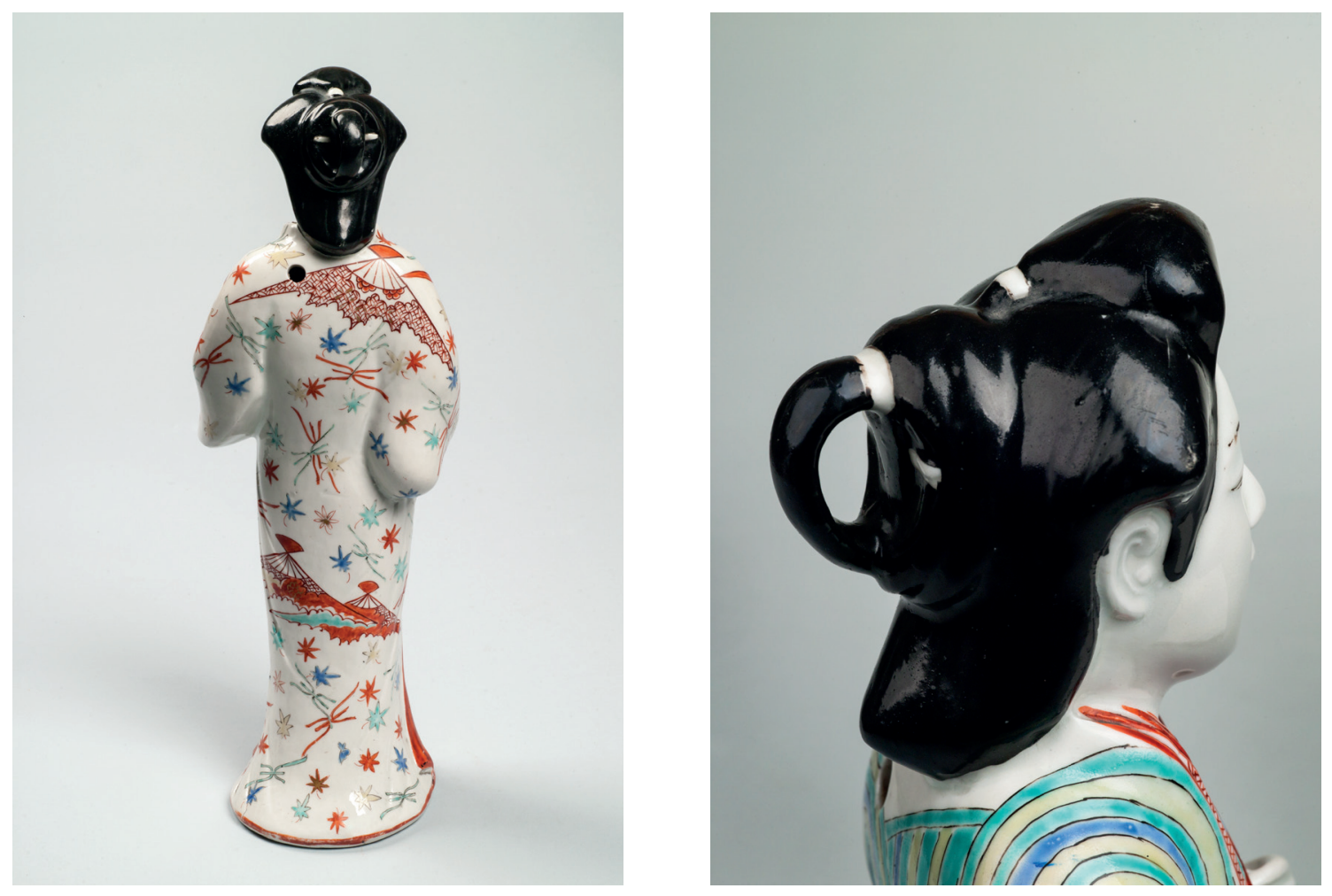

Fig. 3 (left)

Back of the Kakiemon bijin on the left, her robe decorated with fans and maple leaves. Photo: Johan van der Veer

Fig. 4 (right)

Shimada mage, the long hair artfully looped in the back. Photo: Johan van der Veer
The beauties are wearing kosode, literally 'small sleeve', the forerunner of the modern kimono ('thing to wear'). Kosode were worn by men and women alike in Japan until the I9th century. The kosode is characterised by narrow openings for the hands at the ends of the sleeves. The ladies wear kosode over several layers of nagajuban (underkimonos), and both figures have kimono on top of that, secured in place by a black obi, a fashionable item of clothing at the end of the i7th century. Their small feet are covered with a tabi, traditional Japanese socks, with a separation between the big toe and the other toes.

Japanese women's clothes were matched with the seasons. The robe worn by the lady on the right is decorated with a spiral motif and wisteria trailing over trelliswork. Her underkimono is painted with cherry and other blossoms scattered on a chequered pattern, suggesting that this is fashionable attire suitable for wearing in spring, the season of cherry blossoms and wisteria. The patterning on the kimono of the bijin on the left (fig. 3) has broken fans among clouds and falling maple leaves. These motifs are associated with autumn, when, at the end of a hot Japanese summer, fans had to be used all too frequently.

Another extravagant feature of this pair of bijin is their elaborate hairstyles. Hairstyles were very important for Japanese ladies of the Edo period (I603-I867): there were hundreds of different ones and the courtesans were trendsetters of fashionable coiffures. The long hair of these bijin is artfully looped in the back in the shimada mage style (fig. 4). The stylistic features of the Kakiemon bijin are a reflection of a genre

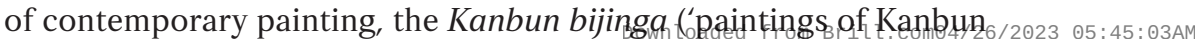


Fig. 5

Kosode, silk, Japan,

Edo-period, late 17th

to early 18th century,

Tokyo National

Museum

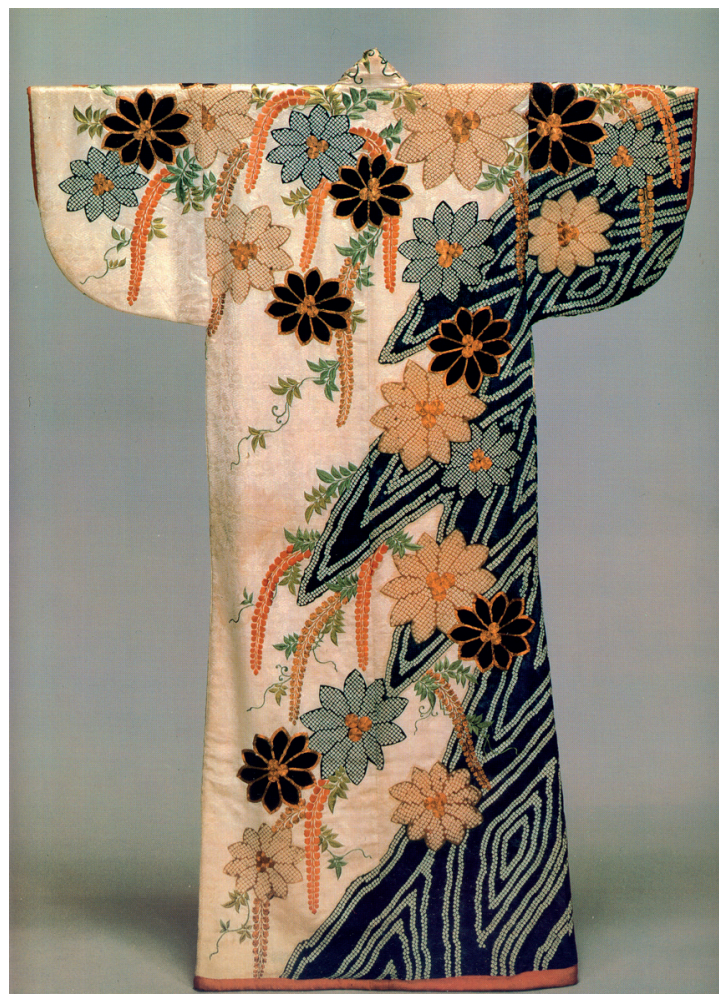

beauties') dating to the third quarter of the I7th century. This term refers to paintings of beautiful women, courtesans, wearing elegant and sumptuous clothing. Most of these paintings were made in Kyoto as expensive souvenirs for wealthy patrons and depict courtesans of the Shimabara pleasure quarter. The Kanbun period only lasted from I66I to I673, but the ideal of female beauty created during this period persisted into the middle of the isth century.

The kimono shown in figure 5 is typical of the Genroku period (I688-I703), which is characterised by vigorous decorations and brilliantly designed robes, often with bold, asymmetrical designs. The pattern of straw hats and maple leaves reminds us of the design of broken fans and maple leaves - and their association with autumn after a hot summer - on one of the Kakiemon bijin's kimono.

\section{The woodblock prints of the ukiyo-e}

The artistic manifestations most characteristic of the Genroku period are woodblock prints of the ukiyo-e, 'pictures of the floating world', of the pleasure quarters and the theatre. Particularly the world of the pleasure districts in Edo, now Tokyo, and Osaka fostered an aesthetic that cherished the passing moment and temporal flux for their own sake. Ukiyo-e represented and reflected a new urban society and culture no longer dominated by the court and the samurai but by the chonin - the rich merchants and artisans. This new class created its own cultural identity: kabuki theatre, light literature, popular arts and the pleasure 2023 05:45: 03 AM 


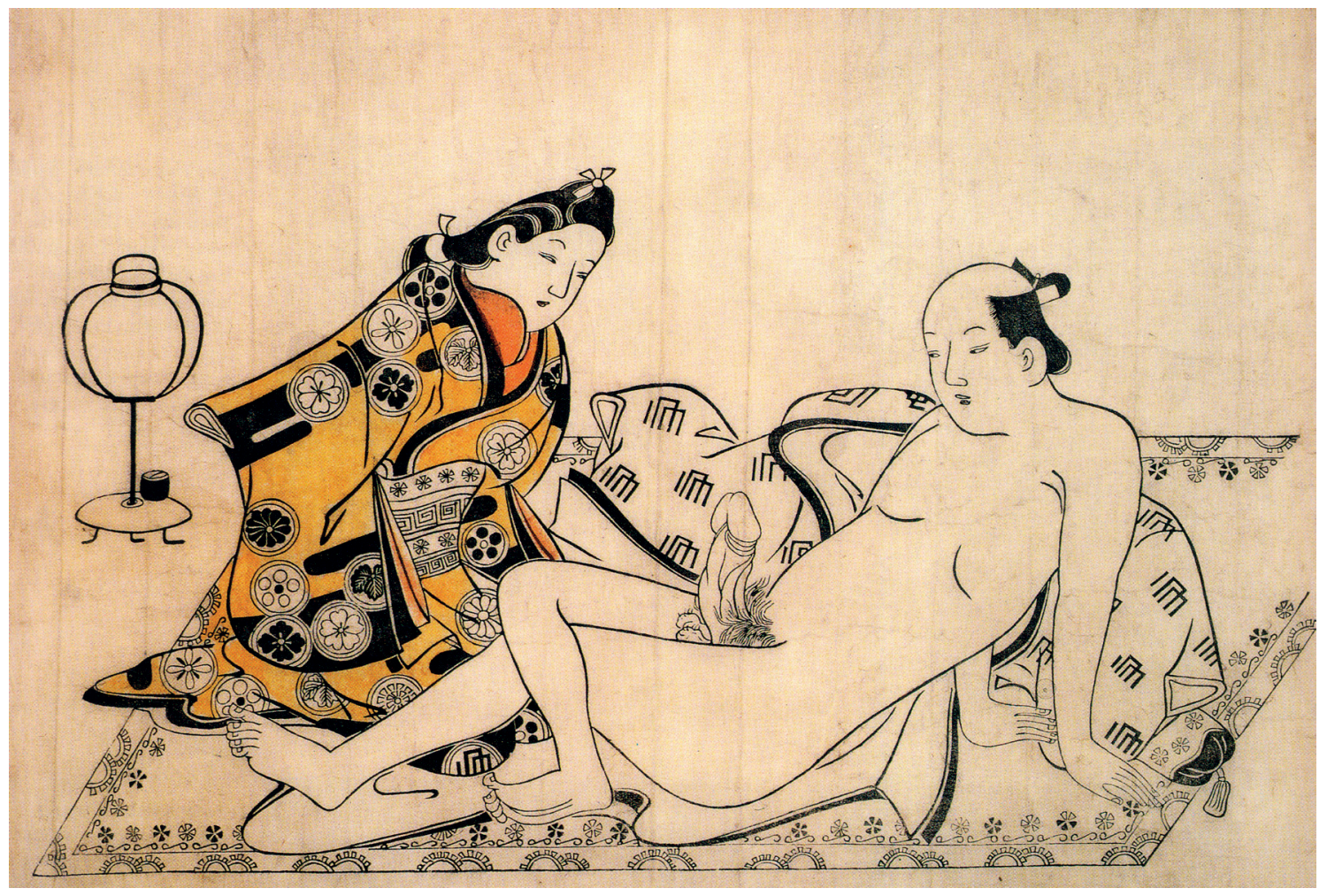

Fig. 6

Hishikawa Moronobu (1618?-1694),

woodblock, ōban,

sumizuri-e, with

hand-colouring,

ca. 1681, Ferry

Bertholet Collection,

Amsterdam quarters. They spent huge sums on art and entertainment. Courtesans, with their gorgeous clothing and fashionable hairstyles, were the 'style icons' of this new urban society (fig. 6).

\section{Courtesans in ukiyo-e and shunga woodblock prints}

A representation of a beautiful woman as an erotic subject in Western tradition exposes her body to draw attention to her nakedness, the attractiveness of her skin, her breasts, and the curve of her hips. The bodies of the Kakiemon bijin, however are not revealed, not even the smallest part. They are fully dressed, even in several layers of fine robes. What, then, makes them sexually attractive? The (Japanese) answer would be: their faces, their robes, their coiffures, and in particular the fact that they are not naked.

This ideal of feminine beauty is represented in contemporary ukiyo-e woodblock prints. One of the most influential artists of his time was Hishikawa Morunobu (I6I8?-I694). Morunobu created illustrated books depicting the world of the pleasure quarters, and many series of erotic prints, shunga, literally 'spring pictures'. In both genres, he propagated the ideal of a rather robust, but elegantly and splendidly dressed woman, comparable to the Kakiemon bijin.

Figure 6 shows a shunga print by Morunobu, dated circa I68I. The courtesan is wearing a sumptuous multi-layered kimono with various crests and her hair is fastened at the top and back with ties in the fashion of the time. She is sitting beside her client, admiring his erect penis sh $_{2}$ The 3 05:45:03Am 


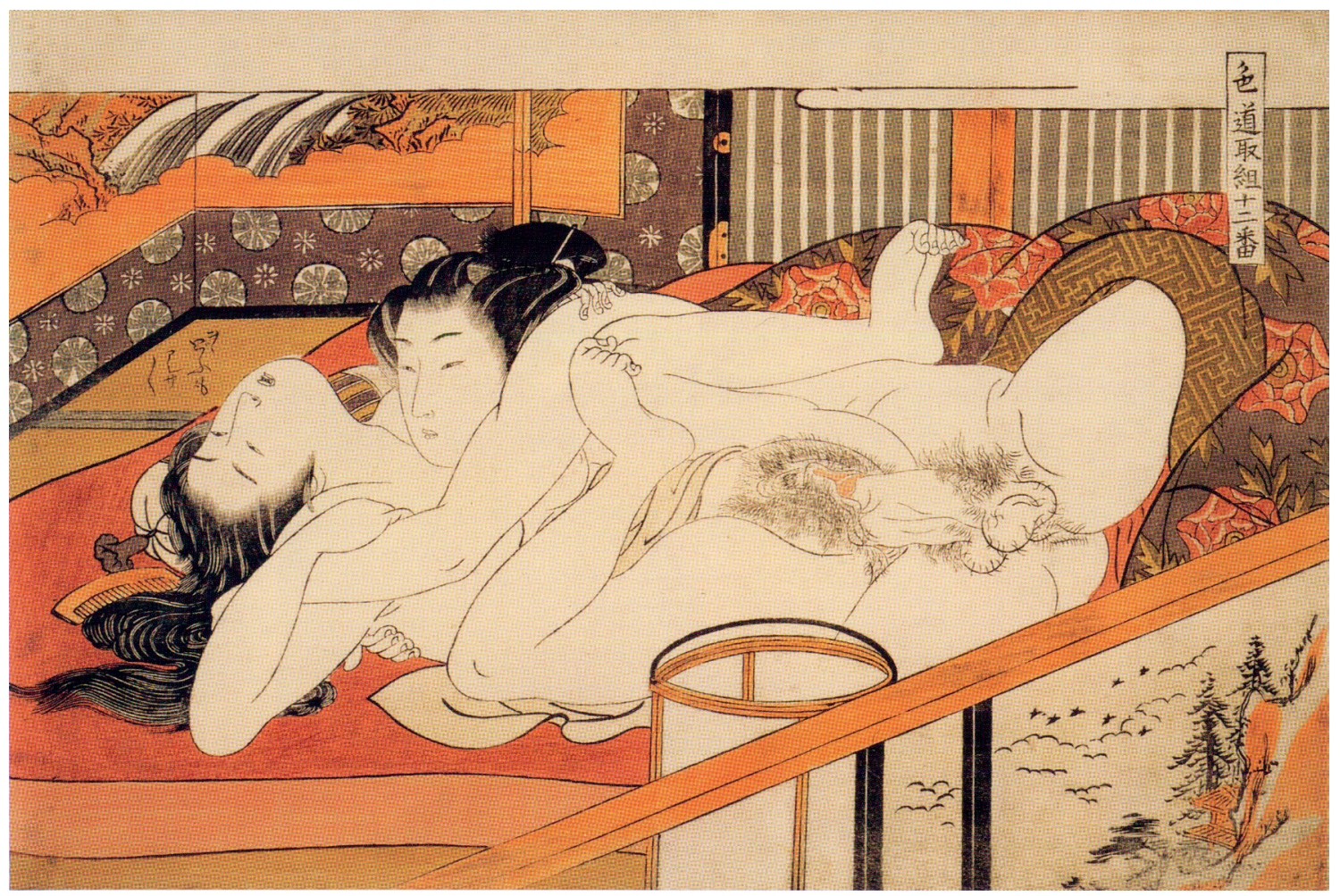

Fig. 7

Isoda Koryūsai,

Twelve Holds of Love (Shikidō torikumi jūniban), woodblock, series of twelve prints, ōban, nishiki-e, ca. 1775-1777, Ferry Bertholet Collection, Amsterdam gentleman, undressed, is reclining on his spread kimono, decorated with the Genji crest (Genji mon), a reference to the IIth-century novel Genji Monogatari by the court lady Murasaki Shikibu.

\section{'Nakedness' in Japanese and Western visual traditions}

The way in which the gender of figures is depicted in East and West is culturally determined. Within the Japanese visual tradition, nakedness did not necessarily connote eroticism and sex, but seemed to suggest merely the discarding of cloths in informal situations, at home or in the local bathhouse. And the nude as a genre, so ubiquitous in the Western art tradition, appeared in Japan only with the introduction of Western painting around end of the igth century.

In the Western visual tradition, the depiction of the nude body is ambivalent: a map of the sexual, or of shame. There is the traditional genre of the idealised naked body of Western antiquity in Greek and Roman arts, and its revival in the Renaissance. However, particularly in the Christian tradition, the unclothed body has often been regarded as shameful, because of its association with sex. Depictions of the naked body in Western art emphasise the secondary sexual characteristics over the genitals. Females are rounder, plumper, have wider hips and more sloping shoulders; males are tauter, narrow at the waist, hairier. Often genitals are not even shown, but the erotic charge is immediately clear. There were also technical issues. Depictions showing erotic or pornographic subjects in Western art were mainly produced as 
copperplate prints, a technique that can render the curves, volumes and muscles of bodies. Shunga were predominantly produced as woodblock prints, which did not allow for much rendition of the roundness of forms, but tended to delineate bodies in outlines. There are of course shunga showing naked bodies - but they are the exception.

In Japanese tradition, there is no polarisation of male and female bodies. In many shunga, male and female bodies are virtually identical. The depictions do not focus on the erotic qualities of skin, or on the curves and hollows of male and female bodies. Even female breasts - as can be seen on many shunga as well as on the two Kakiemon bijin - are downplayed. They are rarely highlighted as sites of sexual interest.

\section{The erotic appeal of clothing}

Illustrating these remarks above, figure 7 shows a shunga from a famous and influential album by Isoda Koryūsai (fl. mid. I760s-I78os), 'Twelve Holds of Love' (Shikodō torikumi jūniban), which was published around I775-I777. The twelve ōban-sized prints show couples in different sexual positions in an interior. Some couples are naked (fig. 7), some are clothed. The bodies of the naked couples are not depicted as distinctly male or female. Even the coiffures, at least for a Western beholder, are similar. Looking at the couple engaged in the sexual act, the genitals, penis and vulva, often in bizarre exaggeration of their size, are the focus of the composition and convey the ecstasy of sexual intercourse.

In most designs, however, the couple is framed and surrounded by dramatically undulating and rippling folds of the finest robes - in most shunga the lovers keep their clothes on. The actual bodies of the men and women or people of the same gender having sex did not seem to interest ukiyo-e artists, or the beholders of these prints and printed books, which were intended to arouse sexual feelings. Therefore, rather than naked bodies, it is the patterns and forms of the gorgeous fabrics that convey the erotic charge. Artists paid painstaking attention to the detailed depiction of fabrics. With shunga, the clothing itself carries sexual weight. A courtesan depicted naked would lose much of her appeal for her wouldbe clients in traditional Japan.

The criteria of what constitutes a woman's idealised and erotic beauty varied greatly between different cultures. These charming Kakiemon bijin figures can be enjoyed for their aesthetic refinement. At the same time, they provide not only more knowledge about the history of Japanese ceramics, but they are also tangible evidence of different concepts of ideal feminine beauty in intercultural crossings.

- Dr. Eva Ströber is former curator of Oriental ceramics at Keramiekmuseum Princessehof, Leeuwarden. Her academic background is Chinese studies, Oriental art history and comparative religion.

- The pair of Kakiemon bijin figures is also included in the exhibition Sexy Ceramics 27 August to 9 July 2017

Keramiekmuseum Princessehof, Leeuwarden 


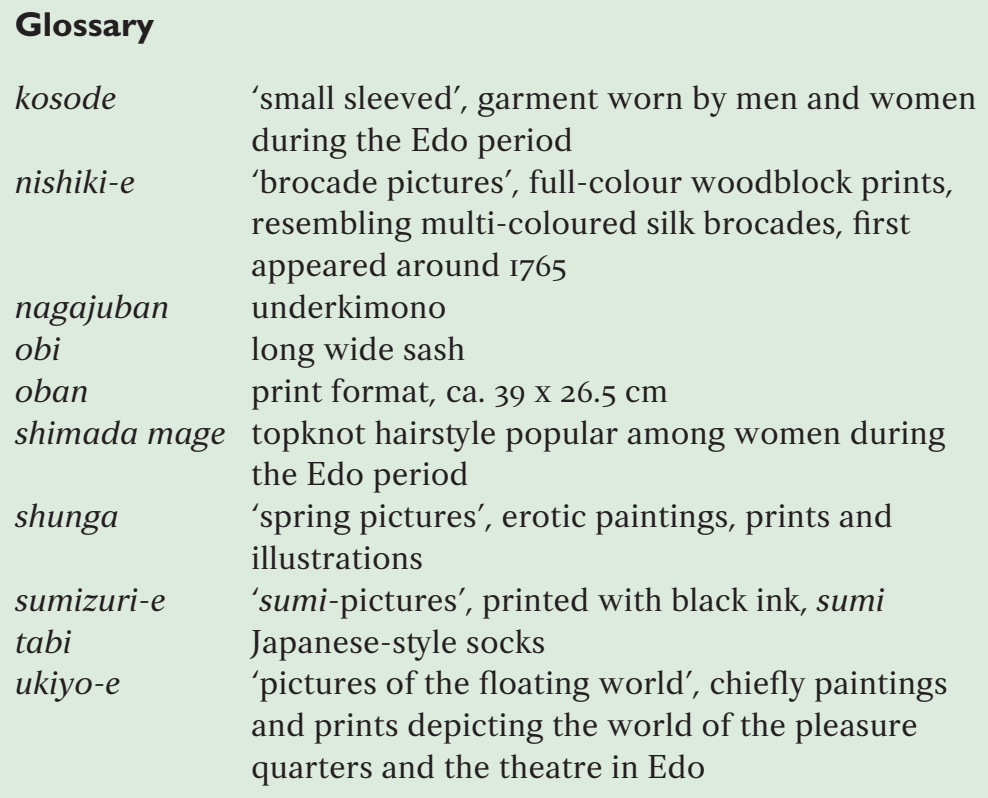

\section{LITERAT URE}

Michel Beurdeley et al., Le Chant de l'oreiller: l'art d'aimer au Japon, Bibliothèque des Arts, Paris, 1979.

Eline van den Berg, 'Ontmoeting tussen oost en west', Bulletin van de Vereniging Rembrandt, 26/2 (2016), pp. 26-28.

Rosina Buckland, Shunga: Erotic Art in Japan, The British Museum Press, London, 2010.

Marco Fagioli, Shunga: Ars Amandi in Giappone, Octavo, Franco Cantini Editore, Florence, I997.

Menno Fitski, Kakiemon Porcelain: A Handbook, Leiden University Press with Rijksmuseum Amsterdam, 20II.

Christine Guth, Art of Edo Japan: The Artist and the City 1615-1868, Perspectives Series, Harry N. Abrams, Inc., New York, 1996.

Alan Kennedy, Japanese Costume: History and Tradition, Greenwich Editions, London, 1994.

Timon Screech, Sex and the Floating World: Erotic Images in Japan I70o-I820, Reaktion Books Ltd., London, 2009 (2nd ed.).

Chris Uhlenbeck and Margarita Winkel, Japanese Erotic Fantasies: Sexual Imagery of the Edo Period, Hotei Publishing, Amsterdam, 2005.

\section{NOTES}

* With thanks to Lukas Kraemer and Aafke Koole.

* Reviewed by Mark Poysden. 


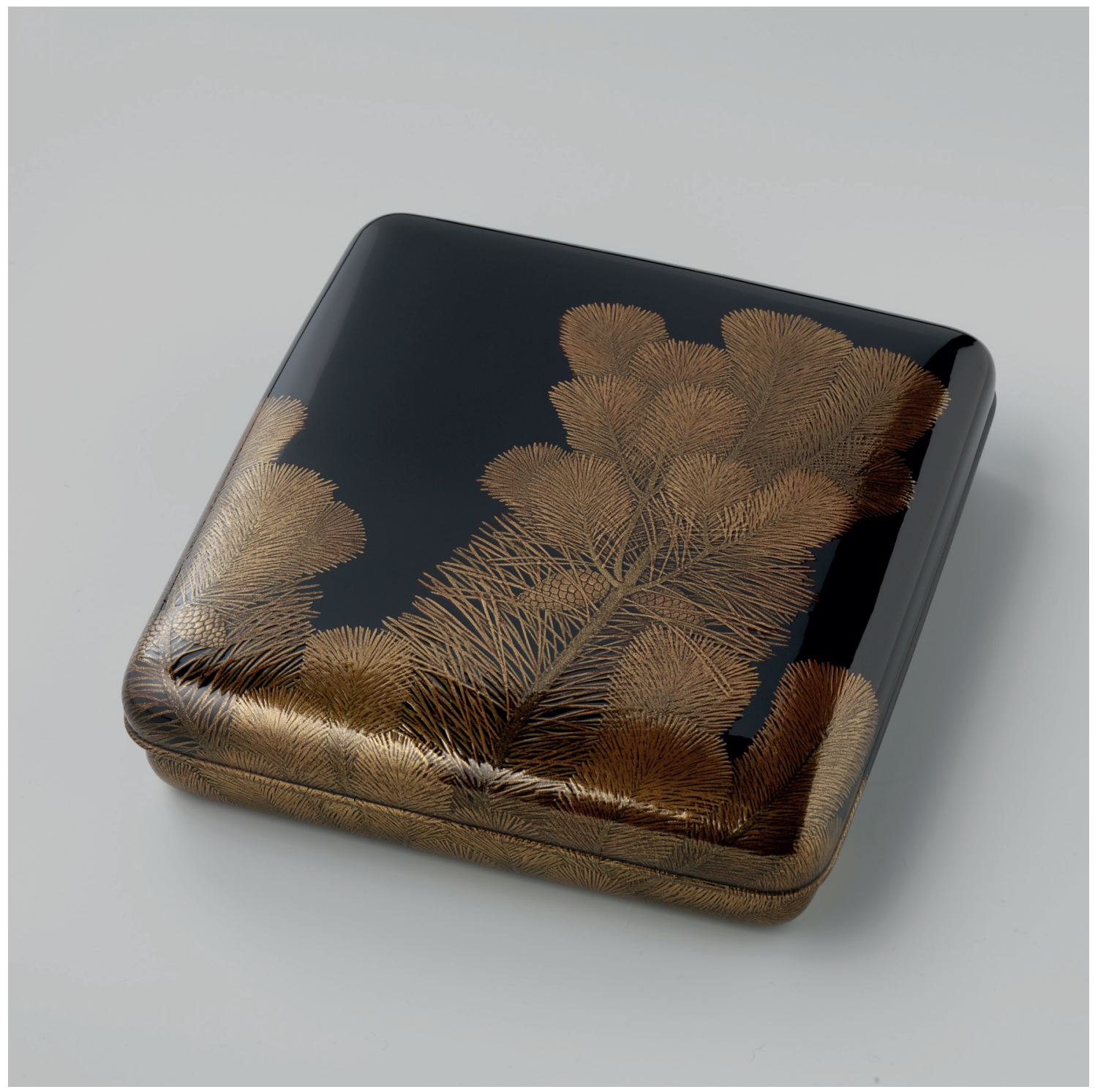

Afb. 1

De schrijfdoos Jonge

pijnboomloten van

Uono Jisei, $26 \mathrm{x}$

24,2 x 6,4 cm, Japan,

1931, Rijksmuseum

Amsterdam,

inv.nr. AK-C-2016-8.

Bruikleen Jan Dees en

René van der Star 